\section{Honey Bee Pollination Requirements for Triploid Watermelon}

\author{
S. Alan Walters ${ }^{1}$ \\ Department of Plant, Soil and Agricultural Systems, Southern Illinois University, \\ Carbondale, IL 62901-4415
}

Additional index words. Apis mellifera, Citrullus lanatus, pollinator, seedless watermelon

Abstract. Honey bees (Apis mellifera L.) are important pollinators of triploid watermelon [Citrullus lanatus (Thunb.) Matsum \& Nakai]. Pistillate (or female) watermelon flowers require multiple honey bee or other wild bee visitations after visiting staminate (or male) flowers for fruit set, and pollination is even more of a concern in triploid watermelon production since staminate flowers contain mostly nonviable pollen. Six honey bee visitation treatments-1) no visitation control, 2) two visits, 3) four visits, 4) eight visits, 5) 16 visits, and 6) open-pollinated control-were evaluated to determine the effectiveness of honey bee pollination on 'Millionaire' triploid watermelon fruit set, yield, and quality utilizing 'Crimson Sweet' at a 33\% pollenizer frequency. 'Millionaire' quality characters (hollow heart disorder or percent soluble solids) did not differ $(P>0.05)$ between honey bee pollination treatments. The open-pollinated control provided the highest fruit set rate $(80 \%)$ and the greatest triploid watermelon numbers and weights per plot compared to all other honey bee visitation treatments. Fruit set, and fruit numbers and weights per plot increased linearly as number of honey bee visits to pistillate flowers increased from 0 (no visit control) to the open-pollinated control (about 24 visits). This study indicated that between 16 and 24 honey bee visits are required to achieve maximum triploid watermelon fruit set and yields at a $33 \%$ pollenizer frequency, which is twice the number of honey bee visits required by seeded watermelons to achieve similar results. This is probably due to many honey bees visiting staminate triploid watermelon flowers (that are in close proximity) before visiting pistillate flowers thus providing mostly nonviable pollen that is useless for fruit set and development. Therefore, more honey bee visits to pistillate triploid watermelon flowers would be required to achieve maximum fruit set and subsequent development compared to seeded watermelons.

Honey bees are important pollinators of vegetable crops requiring pollination for fruit and seed set, and the activity of these insects can be the most limiting factor in watermelon production (Delaplane and Mayer, 2000; Free, 1993; McGregor, 1976; Stanghellini et al., 1997). Watermelon requires insect pollination for fruit set (Delaplane and Mayer, 2000; Robinson and Decker-Walters, 1997; Schultheis et al., 1994; Stanghellini et al., 1997) and many watermelon growers rent honey bee colonies to ensure that maximum fruit set and development occurs.

Pistillate (or female) watermelon flowers require multiple bee visitations after visiting staminate (or male) flowers for adequate fruit set to occur (Adlerz, 1966; Stanghellini et al., 1997; Stanghellini et al., 1998). Pollination is even more of a concern in triploid (seedless) watermelon production since staminate flowers contain mostly nonviable pollen (Rhodes et al., 1997). A standard diploid (or seeded) cultivar (hereafter referred to as a pollenizer) must be interplanted with a triploid cultivar as a source of pollen to ensure that adequate fruit set occurs (Maynard and Elmstrom, 1992; Rubatzky and Yamaguchi, 1997). It is recommended that at least a $20 \%$ pollenizer frequency be used to

Received for publication 18 Dec. 2004. Accepted for publication 24 Feb. 2005. The author gratefully acknowledges technical assistance of personnel at the Southern Illinois University Horticulture and Forestry Research and Education Laboratory (Carbondale, Ill.)

${ }^{1}$ Associate professor; e-mail awalters@siu.edu.
Each of the six treatments was repeated twice on each plant with 10 plants per replication (n $=20$ treatment observations per replication). Watermelon seedlings produced under greenhouse conditions were transplanted at the two to three true-leaf stage into raised beds that were $0.9 \mathrm{~m}$ wide and $2.1 \mathrm{~m}$ center to center. Plots were $12.0 \mathrm{~m}$ in length with watermelon plants spaced $1.2 \mathrm{~m}$ apart in the row.

Standard fertilization and pest control practices for triploid watermelon production in Illinois were followed (Foster et al., 2002). Before bed formation, $34 \mathrm{~kg} \cdot \mathrm{ha}^{-1}$ nitrogen (N), $41 \mathrm{~kg} \cdot \mathrm{ha}^{-1}$ phosphorus (P), and $80 \mathrm{~kg} \cdot \mathrm{ha}^{-1}$ potassium (K) were broadcast applied; plots were side-dressed with $45 \mathrm{~kg} \cdot \mathrm{ha}^{-1} \mathrm{~N} 4$ weeks after planting. Recommended pest control was used, and consisted of spraying a tank mixture of carbaryl [Sevin XLR Plus (less toxic formulation of carbaryl to honey bees); Bayer CropScience, Research Triangle Park, $\mathrm{NC}$ ] and chlorothalonil (Bravo; Zeneca, Inc., Wilmington, Del.) during the evenings when honey bee activity was minimal at recommended rates at 10- to 14-d intervals for the duration of the test. Weeds were controlled by mechanical and hand cultivation. Overhead sprinkler irrigation was used to ensure that plants received at least $2.5 \mathrm{~cm}$ water per week throughout the growing season. At fruit set, irrigation was applied during the afternoon hours as not to interfere with honey bee visitation and pollination.

A strong honey bee colony (about 25,000 honey bees) was placed along the north edge of the field once watermelon plants started to flower. All previous watermelon fruit that had set were removed before the experiment was initiated, as existing fruit load can inhibit additional fruit set (Cunningham, 1939). To control honey bee visits the following day, pistillate triploid watermelon flowers were bagged the evening before anthesis with $3.8 \times$ $5.1 \mathrm{~cm}$ sealed bags. On the day of anthesis, bags were removed to allow 2, 4, 8, 16, or unlimited (open-pollinated control) honey bee visits, and bags did not hinder corolla expansion once removed. The open pollinated control flowers were not monitored for visitor type or number of visitations; these flowers remained open for the duration of the daily sampling period and then the bags were resealed. However, the number of visitations for the open-pollinated control was estimated from about 10 to 15 observations each year. The no honey bee visit treatment was also included as a control. Each time a honey bee landed on a pistillate flower, it was counted as a visit. After each flower had received the desired number of visits, the bag was closed and tagged with treatment and date. Pistillate flowers were removed from plants if they were visited by another type of bee, besides a honey bee. Bags on the open pollinated controls were left open from 0900 until 1300 HR [peak pollen viability and stigmatic receptivity (Sedgley and Buttrose, 1978), and honey bee foraging activity (Ambrose et al., 1995)] and then closed. The bags for the no visit control remained closed the entire day of anthesis. Bee visitation on triploid watermelon was from 29 June to 12 July 1998 and 1 July 
to 14 July 2002. All subsequent pistillate flowers that developed after a honey bee visitation treatment was applied were removed for the next $7 \mathrm{~d}$ regardless of whether it was the first or second fruit set, ensuring that treated flowers ment. The second fruit set was applied to a particular plant as soon as possible after the seven day period had elapsed.

Pistillate flower abortions for each honey bee pollination treatment were recorded to determine the percent fruit set. Watermelon fruit that developed to maturity were hand-harvested, with numbers and weights recorded, and then evaluated for hollow heart disorder and percent soluble solids. Hollow heart disorder was rated on all harvested watermelons from 0 to 9 , with $0=$ no evidence of hollow heart and $9=$ severe hollow heart disorder. Soluble solids concentrations were also determined on heart tissue of all harvested watermelons using a refractometer (Fisher Scientific, Pittsburg, Pa.) measuring from $0 \%$ to $18 \%$ soluble solids.

Analysis of variance procedures were performed using general linear models procedure of SAS (Cary, N.C.) to determine the effects of honey bee visitation over years on percent fruit set, hollow heart disorder, soluble solids, and yields of 'Millionaire' triploid watermelon. Data were also analyzed using regression procedures to determine the influence of honey bee visitation on 'Millionaire' triploid watermelon percent fruit set and yields.

\section{Results and Discussion}

Percent fruit set, and numbers and weights of 'Millionaire' triploid watermelon were affected by honey bee pollination treatment and were given an optimum chance for develop-

year (or growing season), while hollow heart disorder and percent soluble solids were not (Table 1). There were no significant interactions $(P>0.05)$ between honey bee pollination treatment and year. This indicated that the honey bee pollination treatments responded similarly over the 2 years.

No relationships were detected between the number of honey bee visitations and hollow heart disorder or percent soluble solids in 'Millionaire' triploid watermelon. Hollow heart disorder was minor during both years, with $<10$ harvested watermelons showing symptoms of hollow heart each year.

Fruit set rates were $0 \%$ for pistillate triploid watermelon flowers receiving no honey bee visitation (Table 2 ). All honey bee visitation treatments differed $(P \leq 0.05)$ from the openpollinated control for percent fruit set from pistillate flowers, with the open-pollinated control providing the highest fruit set rate of $80 \%$. The highest honey bee visitation treatment evaluated (16 visits) provided a $53 \%$ fruit set rate. As the number of honey bee visits to pistillate flowers increased from 0 (no visit control) to the open pollinated control (about 24 visits), percent fruit set increased linearly $[\mathrm{y}(\%$ fruit set $)=6.02+3.13$ (number of honey bee visits) $\left., r^{2}=0.97, P=0.0004\right]$. These results indicate that between 16 and 24 honey bee visits to triploid watermelon pistillate flowers are needed to adequately prevent fruit abortion compared to the open pollinated control when a $33 \%$ pollenizer frequency is used.

Similar results were obtained for triploid watermelon fruit number and weight obtained per plot (Table 2). Triploid watermelon fruit number and weight per plot were highest with the open pollinated control, and this treatment

Table 1. Combined analysis over years for 'Millionaire' watermelon fruit set rates, yields and quality characters to show significance ( $P$ values) of main effects and interactions. ${ }^{2}$

\begin{tabular}{lccccc}
\hline Main effects and interaction & Fruit set $(\%)$ & Fruit no. & Fruit wt & HH & SS \\
\hline Replication & 0.9136 & 0.9631 & 0.9361 & 0.0695 & 0.7382 \\
Year & 0.0244 & 0.0074 & 0.0001 & 0.0760 & 0.8246 \\
Pollination treatment & 0.0001 & 0.0001 & 0.0001 & 0.1191 & 0.1635 \\
Pollination treatment $\times$ year & 0.0921 & 0.0877 & 0.1135 & 0.6396 & 0.9980 \\
\hline
\end{tabular}

${ }^{2}$ Fruit set $(\%)=$ percentage of pistillate flowers that developed fruit in that treatment; Fruit number $=$ numbers of marketable triploid watermelons per plot; and, Fruit weight $=$ marketable triploid watermelon weights in $\mathrm{kg}$ per plot. $\mathrm{HH}=$ hollow heart disorder was rated from 0 to 9 , with $0=$ no evidence of hollow heart and $9=$ severe hollow heart disorder. SS = soluble solids concentrations were determined on all harvested watermelons using a refractometer measuring from $0 \%$ to $18 \%$ Brix. 'Crimson Sweet' was used as the pollenizer ( $33 \%$ of the total planting).

Table 2. Influence of honeybee visitation treatments on percent fruit set and yields (numbers and weights per plot) for 'Millionaire' triploid watermelon."

\begin{tabular}{lccc}
\hline Honey bee visitation treatment & Fruit set (\%) & Fruit no. per plot & Fruit wt $(\mathrm{kg}) / \mathrm{plot}$ \\
\hline No visit control & $0^{*}$ & $0.0^{*}$ & $0.0^{*}$ \\
2 Visits & $9^{*}$ & $1.8^{*}$ & $5.5^{*}$ \\
4 Visits & $25^{*}$ & $5.0^{*}$ & $32.0^{*}$ \\
8 Visits & $38^{*}$ & $7.5^{*}$ & $46.9^{*}$ \\
16 Visits & $53^{*}$ & $10.5^{*}$ & $68.8^{*}$ \\
Open-pollinated control (about 24 visits) & 80 & 16.0 & 106.1 \\
\hline
\end{tabular}

${ }^{2}$ Data are means of eight replications (four replications per year with the 1998 and 2002 growing seasons combined) with 10 plants evaluated per replication and each treatment repeated twice on each plant in each replicate $(\mathrm{n}=20)$. 'Crimson Sweet' was used as the pollenizer ( $33 \%$ of the total planting). Fruit set increased linearly [y (\% fruit set $)=6.02+3.13$ (number of honey bee visits), $\left.r^{2}=0.97, P=0.0004\right]$ with the number of honey bee visits per pistillate flower. Linear increases were also observed for fruit numbers per plot $\left[\mathrm{y}=1.18+0.62\right.$ (number of honey bee visits), $\left.r^{2}=0.96, P=0.0004\right]$ and fruit weights $(\mathrm{kg})$ per plot $\left[\mathrm{y}=4.96+4.25\right.$ (number of honey bee visits), $\left.r^{2}=0.96, P=0.0002\right]$ with honey bee visitations to pistillate flowers.

"Percent fruit set, fruit number per plot, and fruit weight $(\mathrm{kg})$ per plot comparisons between treatments and the open-pollinated control within the same column were significant at $P \leq 0.05$. differed $(P \leq 0.05)$ from all other honey bee visitation treatments. There was a linear relationship between honey bee visits and 'Millionaire' triploid watermelon fruit numbers per plot $[\mathrm{y}=1.18+0.62$ (number of honey bee visits), $\left.r^{2}=0.96, P=0.0004\right]$ and fruit weights $(\mathrm{kg})$ per plot $[\mathrm{y}=4.96+4.25$ (number of honey bee visits), $\left.r^{2}=0.96, P=0.0002\right]$.

The process of pollination in triploid watermelon stimulates the ovary to enlarge and develop parthenocarpically (Rubatzky and Yamaguchi, 1997); and, fruit set and enlargement is dependent upon growth regulators produced from pollen grains and embryos in developing seeds within the fruit (Hayata et al., 1995). For diploid watermelon, pistillate flowers should receive at least 6 (Stanghellini et al., 1997) or 8 (Adlerz, 1966) honey bee visits for maximum fruit set. The distance of staminate seeded watermelon flowers to triploid watermelon pistillate flowers is of the utmost importance, with triploid pistillate flower distances greater than $6 \mathrm{~m}$ from the seeded pollenizer row causing decreases in yield(NeSmith and Duval, 2001). Since triploid watermelons do not produce sufficient viable pollen to fertilize pistillate flowers (Rhodes et al., 1997), honey bees that carry this nonviable pollen to pistillate flowers are not aiding in fruit development. This hypothesis is supported strongly by the fact that triploid watermelon fruit set required more than twice the number of honey bee visits in this study than did diploid watermelons evaluated by other researchers. In fact, the deposition of nonviable pollen likely hinders pollination, as stigmatic surface area may be obstructed, leaving less space for the deposition of viable pollen (Stanghellini, personal communication).

In summary, this study demonstrates that greater numbers of honey bee visits to pistillate flowers are required for maximum fruit set and development in triploid watermelons compared to diploid watermelons. This is probably due to many honey bees visiting staminate triploid watermelon flowers (that are in close proximity) before visiting pistillate flowers thus providing less viable pollen for fruit set and development. This study further demonstrates the need for interplanted pollenizers as sources of viable pollen in seedless watermelon production systems, and is the first to define the pollination requirements, in terms of honey bee visitations needed to obtain maximum production of triploid watermelons.

\section{Literature Cited}

Adlerz, W.C. 1966. Honey bee visit number and watermelon pollination. J. Econ. Entomol. 59:28-30.

Ambrose, J.T., J.R. Schultheis, S.B. Bambara, and W. Magnum. 1995. An evaluation of selected commercial bee attractants in the pollination of cucumber and watermelon. Amer. Bee J. 135:267-272.

Cunningham, C.R. 1939. Fruit setting of watermelon. Proc. Amer. Soc. Hort. Sci. 37:811-814.

Delaplane, K.S. and D.F. Mayer. 2000. Crop pollination by bees. CAB Intl., Wallingford, U.K.

Fiacchino, D.C. and S.A. Walters. 2002. Diploid pollinizers: effect on triplod watermelon quality and yield, p. 409-413. In: D.N. Maynard (ed.). 
Cucurbitaceae 2002. ASHS Press, Alex., Va.

Fiacchino, D.C. and S.A. Walters. 2003. Influence of diploid pollinizer frequencies on Triploid watermelon quality and yields. HortTechnology 13:58-61.

Foster, R., D. Egel, E. Maynard, R. Weinzierl, M. Babadoost, H. Taber, L. Jett, and B. Hutchison. 2002. Midwest vegetable production guide for commercial growers 2002. Univ. Ill. Ext. Bul. C1373-02.

Free, J.B. 1993. Insect pollination of crops. 2nd ed. Academic Press, London.

Hayata, Y., Y. Niimi, and N. Iwasaki. 1995. Synthetic cytokinin-1-(2-chloro-4-pyridyl)-3-phenylurea (CPPU) - promotes fruit set and induces parthenocarpy in watermelon. J. Amer. Soc. Hort. Sci. 120:997-1000.
Maynard, D.N. and G.W. Elmstrom. 1992. Triploid watermelon production practices and varieties. Acta Hort. 318:169-173.

McGregor, S.E. 1976. Insect pollination of cultivated crops. U.S. Dept. Agr.-Agr. Res. Serv. Agr. Hdbk. 496.

NeSmith, S., and J. Duval. 2001. Fruit set of triploid watermelons as a function of distance from a diploid pollinizer. HortScience 36(1):60-61.

Robinson, R.W. and D.S. Decker-Walters. 1997. Cucurbits. CAB Intl., Wallingford, U.K.

Rhodes, B., K.B. Gruene, and W.M. Hood. 1997. Honey bees waste time on triploid male flowers. Cucurbit Genet. Coop. Rpt. 20:45.

Rubatzky, V.E. and M. Yamaguchi. 1997. World Vegetables, 2nd ed. Chapman \& Hall Publ., New York.
Schultheis, J.R., J.T. Ambrose, S.B. Bambara, and W.A. Mangum. 1994. Selective bee attractants did not improve cucumber and watermelon yield. HortScience 29(3):155-158.

Sedgely, M. and M.S. Buttrose. 1978. Some effects of light intensity, daylength and temperature on flowering and pollen tube growth in watermelon (Citrullus lanatus). Ann. Bot. 42:609-616.

Stanghellini, M.S., J.T.Ambrose, and J.R. Schultheis. 1997. The effects of honey bee and bumble bee pollination on fruit set and abortion of cucumber and watermelon. Amer. Bee J. 137:386-391.

Stanghellini, M.S., J.T. Ambrose, and J.R. Schultheis. 1998. Seed production in watermelon: A comparison between two commercially available pollinators. HortScience 33:28-30. 